\title{
Banishing the Poet: The Pedagogical Function of Mythology in the Dialogues of Plato*
}

\author{
Javier Martínez \\ Universidad de Oviedo \\ martinez@uniovi.es
Destierro del poeta: la función pedagógica de la mitología en los diálogos de Platón

\begin{abstract}
This text attempts to develop a sound justification for Plato's pedagogical use of myth in the dialogues. In particular, I seek to resolve a seeming contradiction: why Plato personally made use of myths in spite of his many statements that seem to contradict such a pedagogical approach, especially his edict that poets and myth-makers be banished from his republic for the danger their works pose to the attainment of true philosophical wisdom. An analysis of the centrality of myths to the dialogues is carried out, followed by a discussion of the place of muthos in its Ionian historical context. This establishes the basis for resolving the contradiction through the division of muthos into two distinct modes: the fantastic and the eikastic.
\end{abstract}

Key words: Myth; Plato's Republic; Banishing of Poets.
En este artículo se intenta desarrollar una justificación del uso pedagógico que hace Platón del mito en sus diálogos. En particular, trato de resolver una aparente contradicción: ¿por qué Platón hace uso de mitos, a pesar de sus numerosas declaraciones que parecen contradecir este enfoque pedagógico, especialmente cuando destierra a los poetas y a los escritores de mitos de su república por el peligro que sus obras representan para el logro de la verdadera sabiduría filosófica? Se efectuará un análisis sobre la importancia de los mitos en los diálogos, y, después, se ubicará el uso del muthos en su contexto histórico jónico. Con ello se establece la base para resolver la contradicción a través de la división del muthos en dos tipos distintos: el fantástico y el icástico.

Palabras clave: Mito; República de Platón; Destierro de poetas.

The works of Plato are unique among ancient philosophers in that Plato utilizes an atypical narrative form, the dialogue, in order to convey philosophical truths, rather than relying purely on logos, or argumentative ap-

* I would like to thank the anonymous reviewers for their helpful comments and suggestions. 
peals to reason. Indeed, one can regard many of Plato's writings as a form of «philosophical fiction», constructed narratives in which the interactions between imagined characters serve to illuminate some central truth by means of example rather than direct logical explication. Indeed, in many of Plato's most famous dialogues, he relies not only on the construction of fictional scenarios involving realistic Athenian characters, but on appeals to Greek mythology and poetry, in order to get his point across. Plato's use of muthos in the context of logos has been the subject of much scholarly inquiry, and it has often been cited that Plato regarded myths as possessing some degree of pedagogical merit. However, this explanation is, in itself, somewhat lacking when taken in the context of the entire body of Plato's works. This is because Plato himself, on numerous occasions, speaks out against the allegorical use of myth as a means of enhancing philosophical understanding and, famously, calls for the banishing of all poets and myth-makers from his utopian republic on the grounds that their works are obstructive to a legitimate understanding of noble philosophical truths. Any adequate justification of Plato's use of myth, then, must resolve these apparent contradictions. Beginning with an examination of some of the most prominent uses of myth in the Platonic dialogues as well as the contemporary historic context for the division of muthos and logos, this text will develop a potential justification for Plato's pedagogical use of myth that resolves the seeming contradictions of the Republic via an appeal to the dichotomous division of myth into fantastic and eikastic components in an earlier dialogue, the Sophist.

\section{Myth in the Dialogues}

The presence of mythological allusions, and later mythological inventions, in the dialogues of Plato suggests that the author possesses an approving critical stance towards mythology. Indeed, myths or at least mythological motifs form a central component of many of his most popular works. This is a view held by the majority of scholars who look at the works of Plato, regardless of their opinion of the dialectical merit of the use of myth. In his now famous critique of Plato's use of myth, Edelstein writes that myths «seem to occupy a fixed and allotted place within the cosmos of his philosophy» (Edelstein 1949 , p. 463). In other words, it seems plain to most scholars that the use of myth in Plato's work is not incidental, but rather a carefully determined decision; the mythological content is not just there, but there for a reason. In 
most cases, Plato's inclusion of a myth is entirely essential to the respective dialogue's thematic intent; one often cannot discern the «meaning» of a given dialogue without considering it in the context of the mythological motif in which Plato has situated it.

One key case in which myth informs Plato's thematic intent is in the Euthyphro. The central question of this dialogue, the question of what constitutes true piety, is not directly handled in an abstract discussion, but rather situated in the concrete context of the experiences of Socrates and Euthyphro. Meeting Socrates at court rather than in his usual place in the Athenian market, Euthyphro asks after Socrates' business and is told of the charges of impiety that Meletus had laid against him. In turn, Socrates is told of Euthyphro's business: he has come to court as a seer to give his opinion on the matter of a local death, and is prepared to level accusations against his own father, because he considers this the proper course of action in spite of the familial discord to which it will expose him. Socrates appeals to several instances of Greek mythology in order to provide a context through which both his and Euthyphro's situations can be better understood: Zeus' chaining up his father Cronus, as well as Cronus' castrating his own father Uranus (Euthyphro 6a173). In this case, Plato's use of mythology serves a clear textual purpose: it not only functions as an allusion to Euthyphro's plans to condemn his own father, but calls into question the very concept of piety as understood by the Athenian courts; indeed, there is a great deal of hypocrisy, as Socrates points out, in the court's attitudes towards the actions of Zeus and Cronus, and their attitude towards his own actions (Billingsley 1991, p. 14).

Elsewhere, in the Phaedrus, the tendency for Plato to rely upon mythology for thematic emphasis becomes even more pronounced. Here, Socrates again makes an appeal to myth in order to illuminate a point about the role of pragmatism in human sexual and romantic relationships. The idea of pragmatic rationality as opposed to "seductive but ultimately empty» passions is clearly common to many of Plato's works (Kluge 2010, p. 347). What is interesting in the Phaedrus is the fact that Socrates employs a myth in order to convey this common theme rather than relying purely upon logical argument. In doing so, it can be said that Socrates successfully provides the context by which to unify the two otherwise disparate topics of the Phaedrus, metaphysical truth and the experience of love, into a cohesive thematic whole (Phaedrus 246a-256e). In other words, Plato has relied on myth rather than logic for a pedagogical and aesthetic purpose, a «means of reconciling truth 
and beauty», a feat which is central to one's full thematic understanding of the dialogue as a whole (Kluge 2010, p. 347).

To further examine this, one might look at the presented dichotomy in greater detail. On the one hand, one is presented with the usual Platonic assertion that the pursuit of truth and the pursuit of the passions are set at odds to one another; that philosophy, reason, and substance lie on one path, and poetry, passion, and ephemeral beauty on another. It is the use of the myth in this context, however, that demonstrates Socrates', and by extension, Plato's understanding that truth and beauty are not necessarily mutually exclusive, and that the superiority of the reason-based approach to truth can be more effectively demonstrated through providing an aesthetically beautiful example. From the standpoint of literary criticism, this use of beauty to indicate truth can also be seen mirrored within the narrative of the dialogue in Socrates' invocation of a physically beautiful boy as a means to elucidate the nature of the «transcendent form of beauty» (Kluge 2010, p. 347). It is through the same means that the myth functions in this context; it provides an appealing attraction for the reader which ultimately points the way to the work's deeper philosophical truths.

Elsewhere, Plato utilizes myths related to the afterlife in order to convey key philosophical points. In the Gorgias, Socrates invokes the mythological afterlife motif of Cronus judging the moral merit of men in a crude dichotomous fashion, emphasizing the point that Zeus is said to have changed the nature of this judgment by requiring that both the judge and those being judged are stripped of their clothing and other worldly trappings (Gorgias 523a). This appeal to myth is used to demonstrate Plato's philosophical points about the unjust politics of tyrants and the unjust use of rhetoric to support such tyrants, as opposed to the less appetitive but ultimately more substantial use of philosophy (Daniels 1992, p. 271). Much later, in the Republic, Plato famously uses a myth entirely of his own creation, the myth of Er, to expound upon a similar philosophical premise: the idea that «the happy life is the just life» (Johnson 1999, p. 3). The use of the myth in this context is essential for clarifying the theme that just behavior is inherently rewarding, a point that would be plainly unconvincing if expressed in a purely logical fashion, without appeal to the beauty of the Er myth.

In short, it is evident not only that Plato frequently uses myths in his philosophical writings, but also that his appeals to myth are essential. In many cases, these appeals made by Socrates or by Plato directly not only 
enhance the theme or message of the work, but are critical to conveying a sensible understanding thereof. It is this fact, however, that makes Plato's later banishment of the poetic tradition from his hypothetical republic all the more puzzling (v.gr. Republic 398a-b, etc.). This is especially true when one considers that his use of myth is not only seemingly in contradiction to his own statements on the merits of poetry, but also in contradiction to the cultural expectations for philosophical writing during the time in which he lived.

\section{Muthos in its Historical Context: The $6^{\text {Th }}$ Century BCE}

Expounding upon the use of myth in Plato's philosophical works requires an in-depth understanding of the historical context of the literary tradition in Greece during Plato's lifetime. There is a great deal of historical and scholarly evidence to suggest that an ideological shift occurred in the $6^{\text {th }}$ century $\mathrm{BCE}$, during which a deep sense of division emerged between the traditions of muthos and logos (Bargeliotes \& Triantou 2005, p. 107). Prior to this point, one might observe, such as in the works of Homer and Hesiod, that mythic and intellectual traditions «very often ... penetrate each other, in order to dissociate later on» (Bargeliotes \& Triantou 2005, p. 107). For instance, one might observe the pedagogical tradition in ancient Greece of memorizing extensive passages from Homer. This can perhaps be viewed as being connected to the status of mythology as the officially recognized state theology at that point in time. Whatever the case, circumstances began to change in the $6^{\text {th }}$ century, when this state endorsement of myth began to dissolve in favor of a greater emphasis upon empiricism and reason.

This trend can be said to have begun with the Ionian philosophers of the $6^{\text {th }}$ century, who are credited with initiating a de-emphasizing of mythic content in literature because of myth's apparent lack of utility as a means for effectively explaining the natural world (the goal of works driven by $\log o s$ ) (Bargeliotes \& Triantou 2005, p. 107). As a consequence of this more rational approach to explaining the universe, philosophical works soon relegated the use of myth to a sub-function as explanatory rhetoric, and this was true only in the most permissive circumstances. Many philosophers in the two centuries before Plato condemned the use of myth outright, having «discarded [it] as unworthy of him who searches for knowledge» (Edelstein 1949, pp. 463-464). When Plato began writing after centuries of such thinking, it 
would have been natural for him to adopt a similar way of thinking towards the dichotomy between muthos and logos.

Indeed, some of Plato's own writings seem to indicate a stance on the issue that is very much in keeping with the popular prevailing opinions of the time. Despite the above cited use of myth in the Phaedrus to convey the philosophical messages of that dialogue, it also contains one of Plato's most clear and direct statements on the allegorical use of myth (Phaedrus 229e-

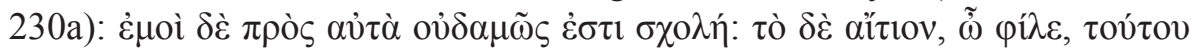

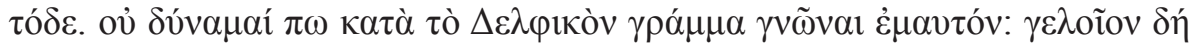

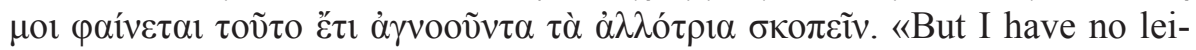
sure for them at all; and the reason, my friend, is this: I am not yet able, as the Delphic inscription has it, to know myself; so it seems to me ridiculous, when I do not yet know that, to investigate irrelevant things» (trans. H.N. Fowler). While it can be problematic to ascribe the views of Socrates to Plato himself, this nevertheless suggests a certain reluctance of attitude towards the acceptance of muthos as an integral part of philosophical inquiry. Indeed, it seems particularly at odds with the fundamentally logos-driven Socratic method, save for one fact: often when Socrates appeals to a myth in these early dialogues, he states that while his interlocutors will view it as a false story, he himself regards the myth as true (see, for instance, Gorgias 523a). This suggests that even while preserving the contemporary view of muthos and logos as distinct, Plato understands that the use of muthos could subordinately point to the truthful object of a logos-driven argument.

However, such a claim brings one back to the initial point of contention: if Plato recognizes the instructional value of muthos, why does he decry myth and poetry as antithetical to learning in the Republic? Indeed, it is plain that Plato's utopian view entails the denouncing of «the poetical as well as the mythological-religious speech, as a speech entirely impious, which obscures, gives false images of the gods and the heroes, excites the passions of the soul, diverts morals and lapses away from the area of mere truth» (Bargeliotes \& Triantou 2005, p. 108). This concept of the elegant «mere truth» is quite appealing within the context of Plato's writings, being the object of all Socratic inquiry, which seeks to gradually strip away all obfuscation and confusion, leaving behind a singular truth supported by logos. Even contemporary authors, moved by the elegance of the truth exposed by Socratic methods, have spoken out against the occasional Platonic appeal to myth, deeming it an «unbecoming habit» (Trainer 2007, p. 31). 
Nevertheless, one cannot discount the fact that, for all his denouncing, Plato nevertheless does support his logical presentation of «mere truth» with poetry and myth.

\section{Plato’s New Context for Muthos}

The natural conclusion to draw from this apparent contradiction is that, even while Plato might have discounted the philosophical value of the myth, he nevertheless was «aware of the limitations of logical argument» (Edelstein 1949 , p. 464). In other words, Plato viewed the use of myth as an essential aspect of his duty, as an essentially Socratic philosopher, to educate those around him. In this sense, the function of a logical argument is severely limited. While a logical argument appeals to the philosopher, it is often unconvincing, or at least less convincing, to the average person whose passion for pure philosophy has not yet been kindled. In this sense, it is plain to see why Plato would have been drawn to use myths, while also reluctant to do so. Indeed, as will be further explicated, in the Republic, the use of myth is superficially anathema to the Platonic and Socratic methods of pursuing the truth. For Plato, especially, who asserts the existence of Forms, myths must be regarded as simply another obfuscation which stands in between one's understanding and the plain objective truth of the Form, the thing which exists.

Nevertheless, as Plato would have been well aware of, there are some things which fall under the domain of philosophical discussion that cannot be directly perceived or experienced in a purely rational way. For example, topics such as the nature of the human soul, or the nature of the further reaches of the cosmos, cannot be handled entirely in rationalistic terms, because there is no living human who has empirically experienced such phenomena. On these matters, one can «discourse only in pictures of imagination» (Edelstein 1949, p. 464). It is with this understanding that Plato's acceptance of myths begins to seem more consistent with his statements on the logical value of said myths.

In essence, while Plato may deride myths for existing apart from the truth, and in many cases, acting to obscure the truth through layers of separation from the Form, he still recognizes the allegorical value (if not the logical value) that myths can possess. Even though passages attributed to Socrates disparage the use of allegory, as established above, the allegorical function of myth was nevertheless the commonly accepted use of myth among the 
Ionian philosophers of the $6^{\text {th }}$ century BCE (Benitez 2007, p. 225). It is easy to see how the allegorical use, while perhaps not ideal, could still be appealing to Plato, in that allegory serves to establish a more or less direct link between the myth itself and the object to which it refers, fulfilling a clarifying function rather than an obfuscating function.

Interestingly, this concession by Plato places his use of myth in a new context not otherwise employed during the Ionian era, achieving something closer to the synthesis of muthos and logos seen in Homer and Hesiod. This new context can be best understood by categorizing myths and qualitatively distinguishing between them on the basis of content and instructive value. While this may seem like a major assumption to make about Plato's methodologies, one might refer to his dialogue The Sophist. In this text, a figure known as the Eleatic Stranger famously draws an aesthetic distinction between what he sees as two separate types of myths: fantastic myths and eikastic myths.

The distinction between the two types of myths is made on the basis of aesthetic intent (Benítez 2007, p. 225). Those myths which are said to focus on the presentation of an aesthetically pleasing experience, through the distortion of actual reality (for instance, tragic plays or poetry), are regarded as fantastic myths. For Plato, these myths are those with the greatest likelihood of misleading people, and which have the least regard for the truth; as such, they have the least pedagogical value and have no place in a work of logos. These are the works of those poets whom Plato seeks to banish from his utopian Republic. By contrast, those myths which strive to accurately reproduce reality in some meaningful way through «employing the right perspective and accurate proportions», are said to be eikastic myths (Benítez 2007, p. 225). Such myths can be used in a work of logos, because they serve as the aforementioned bridge between representation and reality, rather than working to obscure reality for the sake of aesthetics. Plainly, if the distinction between fantastic and eikastic myths can be drawn on the basis of whether or not a given myth illuminates or obscures its reality-based referents, all of the myths utilized in the Platonic dialogues, as outlined above, are fundamentally eikastic in nature as they serve to illuminate philosophical truths rather than obscure them.

Thus, by embracing the pedagogical utility of eikastic myths, Plato is better able to fulfill his own prescribed civic duty as a philosopher, and instill his philosophical works with a quality that is more appealing and accessible to the average reader, without hypocritically degrading the quality of his $l o-$ 
gos. Plato's use of myth, then, can be regarded not purely as an aesthetic choice, but rather a functional «instrument in the dialectical process» (Bargeliotes \& Triantou 2005, p. 109). Because his dialogues must often make considerable reference to subjects and objects that lie beyond the scope of direct empirical experience, it becomes necessary to provide examples of these things by whatever means possible; since no direct experience is possible, indirect experience through carefully constructed myths, themselves possessing elements that are familiar to his audience, offers the best technique for expressing «whatever is inexpressible by literal language» (Bargeliotes \& Triantou 2005, p. 109).

A simplistic example of the use of the eikastic myth to close the gap between mythic representation and reality can be found in the Republic, in the famous eikón (better for the common «allegory» as pointed out by Gilabert 2010) of the cave. Here, Plato describes the experience of a figure chained in the dark and exposed only to vague and ambiguous representations of reality, «shadows» reflected by a fire. While the figure's contemporaries all regard these shadows as the literal objective truth, the figure himself would be able to loosen his bonds and escape from the cave, where he discovers the actual Forms of reality that are casting the shadows. Within the context of this mythic analogy, Plato chooses to represent the concept of the supreme good as a light which illuminates everything in a harsh and unrelenting manner: the sun. This is the fundamental structure of an eikastic myth: the message is situated in a fictional context (a society chained inside a cave), but uses symbols and objects knowable to the senses (the sun) to convey truths about the nature of things that are not directly knowable to the senses (the idea of «supreme good»).

Interestingly, the philosopher who escapes from the cave faces a predicament remarkably similar to Plato's own. Here is a figure who has seen and comprehended the Forms of reality directly, and who is sadly incapable of conveying these truths to his contemporaries who remain chained up in the cave. They dismiss his assertions as groundless flights of fancy, because they are so alien to their own experiences. Thus, just as Plato must struggle to make his logos intelligible to his untrained audience in the fulfillment of his civic duty as a philosopher, the figure from the eikón of the cave must also struggle to «make himself understandable to people who don't possess a special theoretical training» (Bargeliotes \& Triantou 2005, p. 110). Ultimately, he is unable to convince those around him of the truth of the Forms by pointing to the Forms directly, because those who remain chained lack the 
necessary faculties with which to behold the Forms; figuratively, they are incapable of viewing objects lit by the sun directly, because the light is too harsh and glaring for their sense of vision, which has been dulled by spending years in the dark. Rather, he must use the shadows themselves to convey his understanding of the truth, slowly and incrementally, in such a way that can be understood by those who remain chained, and it is in this context that the pedagogical value of myth in philosophy is laid bare: myth becomes «an instrument of the soul's diversion ... piloting towards the great and significant subjects» (Bargeliotes \& Triantou 2005, p. 110). The analogy to Plato's own experience is plain; he cannot rely purely upon logos, or direct rational appeals to knowledge, because such is unintelligible to his audience; rather he must make use of what is intelligible, muthos, to make himself heard. In this sense, myths become «those shadows that show their own shadow-like nature», and which must work «hand in hand with dialectic» in order to produce truly effective pedagogy (Hooper 2010, p. 843).

The epitome of this eikastic use of myth in the works of Plato occurs, somewhat ironically, at the end of the Republic, the very same work in which the philosopher calls for the banishing of poets from his utopian vision. After presenting an argument founded in logos for the impetus to live a just life, making the claim that one who lives a just life will by necessity also live the happiest life, Plato follows up with a self-constructed eikastic myth known as the «Myth of Er». This myth follows the activities of several prominent figures from Hellenic myth and literature as they find their way through the afterlife and proceed towards a form of reincarnation. Along the way, they encounter various scenarios in which the value of reason and just behavior is explicated, not only in earthly life, but in the next as well. In presenting a mythic counterpoint to his logos, Plato fully returns to the synthetic treatment of muthos and logos that was characteristic of the Hellenic tradition from which he borrows symbols and characters (Wang 2009, p. 282). Some critics have thusly regarded the myth of Er as «a philosophical rewriting of poetry» in which the virtues of the poetic form are fully bent to Plato's instructive and pedagogical purpose (Wang 2009, p. 282).

\section{Myth And the Noble Lie}

Having determined a probable rationale for Plato's inclusion of myth in his dialogues, it is still necessary to resolve the fundamental paradox between 
this rationale and the decree that poets and myth-makers are to be banished from the republic, due to the harm their works do in obscuring understanding of the truth. One might attempt to resolve such a contradiction by an appeal to the fantastic and eikastic dichotomy of myth, asserting that Plato meant only that fantastic myths are to be abandoned, but this is not explicitly indicated anywhere in the text; it can only be inferred.

The proper resolution to this seeming contradiction on the part of Plato lies in the fact that not all poetry and myth is banished from the republic. Indeed, one remains, which is to be perpetuated by the masters of the republic themselves: the «noble lie». In the third book of the Republic, Plato expresses the need for the regimented order of the republic to be maintained by means of a carefully calculated illusion, a «noble lie» which gives individual citizens of the republic an impetus to behave justly and maintain the necessary order. This «noble lie» takes the form of an invented creation myth, in which the gods who created humanity are said to have instilled different individuals with one of three types of precious metal: gold for those individuals fated to rule the republic and hold executive offices, silver for those who defend the city or aid it in some fashion, and iron or brass for those who perform the menial tasks that nonetheless support the continuation of the republic: farming, smithing, building, and so on (Republic 414e-415c). Notably, the instilling of these metallic symbols of quality is not hereditary; golden parents may give birth to iron or brass offspring, and vice versa. Therefore, the myth does not espouse fatalism, so much as a crude meritocracy wherein the meritorious virtues of each individual are judged, and the individual is then placed in the appropriate caste accordingly, such that the tripartite order upon which the republic depends can be maintained. Plato asserts that the use of a myth to make this regimentation more comprehensible and palatable to the populace will make it significantly easier to maintain order by giving each citizen a shared reason to participate in that order (Republic, 415d).

At first, the invocation of the noble lie might seem to only further bolster the idea that Plato is contradicting himself; after all, he first banishes the poets as dangerous to his republic, but then immediately makes personal use of poetry as a means to ensure the success of that republic. However, one must not fail to view this contradiction, as mentioned, in terms of the fantastic and eikastic dichotomy.

Indeed, one must examine not just Plato's dismissal of the poets from the republic, but the three reasons he gives for doing so. In the first place, poets 
are dismissed because their works tend to obscure rather than illuminate the important topics of philosophical inquiry. They serve ultimately to erect barriers before people's understanding of the Forms, further separating them from reality through the process of representation distorted for aesthetic purposes. However, as determined above, Plato's own use of muthos in the support of logos steps around this criticism by using myths that are carefully constructed, not so much for aesthetic appeal, as for their pedagogical value, their ability to accurately reveal the Forms to which they refer, particularly when those Forms are intangible and unable to be discerned directly with the senses. Certainly, the use of the noble lie falls into this category of an eikastic myth; it lacks the beauty of Plato's earlier use of myths such as in the Phaedrus or Timaeus, and is more directly utilitarian in its construction.

Secondly, Plato banishes poets from the republic for the reason that poets have a tendency to place aesthetic emphasis only on those parts of the human soul which are, in Plato's mind, least worth regarding and studying. Few are the poems about the beauty of truth and reason, for instance, while the appetitive parts of the soul are frequently depicted in poetic form, for the sake of aesthetic gratification. Again, however, the noble lie does not fall under the auspices of this criticism; in fact, it serves the eikastic function of providing a concrete example of the tripartite division of the soul which is directly analogous to the tripartite division of social classes upon which the success of the republic depends.

Lastly, the banishing of the poets is justified by the tendency for poetry to incite inappropriate feelings of pity and sympathy in citizens, causing them to sympathize with those figures of poetic regard who engage in tragic selfdestruction through appetitive pursuits. This is, once again, a criticism only valid when applied towards fantastic mythology; it does not constitute a contradiction for Plato to make use of an eikastic myth such as the noble lie, even after an injunction to «banish all poetry».

While one can make a valid criticism that the noble lie is a form of a tyranny which actually obstructs the pursuit of philosophical truth by superimposing an innate categorization of humanity which does not metaphysically exist outside the edicts of the state, the fact remains that the pedagogical virtue of the noble lie has been effectively demonstrated in various real world contexts outside the work of Plato. Much has been written about the use of the noble lie in American civic education, for instance, wherein civic identity is regarded as being pedagogically constructed through the forma- 
tion in the classroom of «the meaning of national identity» (Burch 2007, p. 111). In particular, critics have cited the use of carefully skewed historical narratives, themselves a form of eikastic myth, to purposively construct a sense of national identity similar to the «precious metals» identity which Plato hoped to instill; for instance, the commonly taught narrative that Columbus «discovered America» in some heroic and laudable fashion is a form of eikastic myth that dispenses with historical fact in order to engender a sense of patriotism and civic duty in the population. The control of discourse and narrative by the state establishes conditions wherein national identity is easily manipulated into serving the interests of states; as another example, it might be argued that the plainly constructed narratives surrounding the justification of the Iraq War, and the success such narratives had, regardless of truthfulness, at convincing the Western public of the necessity of said war. However, the contemporary student of Plato maintains an advantage that the hypothetical citizen of Plato's republic did not: one is fully aware of the mythic nature of the noble lie, and as such has the capacity to critically evaluate the use of such lies by the state. In this way, one might judge that Plato's use of the noble lie in the Republic has served an ultimately antityrannical purpose, providing the citizen with instruction in the techniques of authoritarian statecraft, so that these techniques might be understood, critiqued, and overcome.

Ultimately, it is an excessively simplistic interpretation of Plato to say that his banishing poetry is a contradiction when taken in the context of his own use of myth. Rather than utterly devaluing poetry like some Ionian philosophers, and as he himself seems to in some early dialogues, Plato openly acknowledges the pedagogical function of eikastic myth and poetry. It is only poetry for poetry's own sake, the creation of myths derived from purely aesthetic considerations, that Plato considers to be harmful to the soul and obstructive of learning and education. By contrast, myths which are purposively constructed to illuminate a philosophical truth are not only permissible, but in fact actively necessary in order to fulfill the civic duty of the philosopher to improve the moral identity of the citizenry.

\section{REFERENCES}

Bargeliotes, L., \& Triantou, P. 2005: «The cognitive role of Plato's use of mythos», Dialogue and Universalism, 15.3, pp. 107-115. 
Benítez, E. 2007: «Philosophy, myth, and Plato’s two-worlds view» European Legacy, 12.2, pp. 225-242.

Billingsley, D. 1991: «Myth and dialogue in Plato's Euthyphro», College Literature, 18, pp. 14-24.

Burch, K. 2007: «Plato's myth of the noble lie, and the predicaments of American civic education», Studies in Philosophy and Education, 26.2, pp. 111-125.

Daniels, Ch. 1992: "The afterlife myth in Plato's 'Gorgias'», Journal of Value Inquiry, 26.2, pp. 271-279.

Edelstein, L. 1949: «Function of the myth in Plato's philosophy», Journal of the History of Ideas, 10, pp. 463-481.

Gilabert, P. 2010: «La imagen de la caverna y la tentación constante de corregir a Platón: Benjamin Jowett como ejemplo», Estudios Clásicos, Anejo 1, pp. 103113.

Hooper, A. 2010: «The philosopher's stories: The role of myth in Plato's pedagogy», European Legacy, 15.7, pp. 843-853.

Johnson, R. 1999: «Does Plato's myth of Er contribute to the argument of the Republic?», Philosophy and Rhetoric, 32.1, pp. 1-13.

Kluge, S. 2010: «Eros as 'Pteros'. Allegorical mythology in Plato's Phaedrus». Orbis Litterarum, 65.5, pp. 347-371.

Trainer, Ch. 2007: «Treason to truth: The myths of Plato», Philosophy Now, 62, pp. 31-34.

Wang, K. 2009: «Plato's poetic wisdom in the myth of Er», Frontiers of Philosophy in China, 4.2, pp. 282-293. 